\title{
UMELECKÉ ŤAŽENIE REŽISÉRA PETRA KONWITSCHNÉHO PROTI „MŔTVEJ OPERE“
}

\author{
MICHAELA MOJŽIŠOVÁ \\ Ústav divadelnej a filmovej vedy Centra vied o umení Slovenskej akadémie vied, Bratislava
}

\begin{abstract}
Abstrakt: Text sa zaoberá vybranými princípmi tvorby nemeckého operného režiséra Petra Konwitschného. Celoživotnou ambíciou umelca, ktorý otvorene proklamuje lavicovú hodnotovú orientáciu, je vyrušit diváka z konzumného oddávania sa krásnej hudbe a urobit ho spoločensky zodpovedným, premýšllajúcim účastníkom inscenácií. Počas polstoročnej kariéry si vytvoril stabilnú databázu izotópií, prostredníctvom ktorých napĺňa svoju ideu - od rozsvecovania svetiel v hladisku až po riešenia pripomínajúce stratégie imerzného divadla. Autorka v štúdii prezentuje príklady z viacerých inscenácií, ktoré Peter Konwitschny vytvoril na európskych javiskách, vrátane Slovenského národného divadla v Bratislave.

Kl'účové slová: operné divadlo, Peter Konwitschny, „'mŕtva opera“", Bertolt Brecht
\end{abstract}

Celoživotnou, konzekventne napíňanou umeleckou ambíciou režiséra Petra Konwitschného je boj proti „mŕtvej opere“. Týmto sugestívnym výrazom, ktorý možno považovat’ za synonymum pojmu ,kulinárske umenie“ zavedeného predstavitel'mi Frankfurtskej školy na čele s muzikológom Theodorom Adornom, Konwitschny $\mathrm{v}$ rozhovoroch, príspevkoch $\mathrm{v}$ bulletinoch a odborných textoch opakovane označil ilustratívne, iluzívne divadlo bez pridanej výpovednej hodnoty. „Najsvojráznejší študent Ruth Berghaus “1, ako ho v laudatiu pri príležitosti 40. výročia profesionálnej činnosti nazval nemecký muzikológ Gerd Rienäcker, je presvedčený o tom, že „opera má zmysel iba vtedy, ak prostredníctvom nej povieme niečo užitočné o katastrofickom stave našej civilizácie ${ }^{\prime 2}$. Adresáti jeho inscenácií sa nemajú pasívne oddávat’ estetickému zážitku, z divadla musia odíst’ zasiahnutí, znepokojení, premýšlajúci. Obecenstvo považuje za dôležitého partnera svojich koncepcií: „Divadlo nie je múzeum. Podstatou divadelného predstavenia nemôže byṫ zhmotnenie intencií autora, ako ich predostrel pri pôvodnej premiére diela (alebo skôr, ako si my dnes predstavujeme, že ich predostrel). Zmyslom divadelného predstavenia je predovšetkým viest’ dialóg s publikom o témach podstatných tak pre spoločnost', ako aj pre životy jednotlivcov. Ako povedal Brecht, divadelné diela k tomu len poskytujú materiál. ${ }^{\text {“3 }}$

Peter Konwitschny si počas takmer polstoročnej profesionálnej činnosti vypracoval bohatú databázu izotópií, ktorými divákov vytrháva z recepčného pohodlia, aktivizuje ich spoločensko-kritické vnímanie a apeluje na občiansku zodpovednost'.

${ }^{1}$ RIENÄCKER, G. 40-jähriges Bühnenjubiläum. In WELKER, A. (ed.). Peter Konwitschny. „Mensch, Mensch, Mensch!“ Oper als Zentrum der Gegenwart. Weitra : Verlag Bibliothek der Provinz, 2015, s. 166.

${ }^{2}$ KONWITSCHNY, P. - HOLTZ, C. Bach inszenieren heisst mit der Endligkeit vertig werden. [rozhovor]. In Neue Zürcher Zeitung, 28. 5. 2011. [online]. [cit. 17. 9. 2019]. Dostupné na internete: https://www.nzz.ch/ bach_inszenieren_heisst_mit_der_endlichkeit_fertig_werden-1.10727684.

${ }^{3}$ KONWITSCHNY, P. - SKRAMSTAD, P.-E. - HOLTE, K. I do not consider myself a representative of the Regietheater. [rozhovor]. In Wagneropera.net. [online]. [cit. 20. 9. 2019]. Dostupné na internete: http:// www.wagneropera.net/Interviews/Peter-Konwitschny-Interview-2009.htm. 


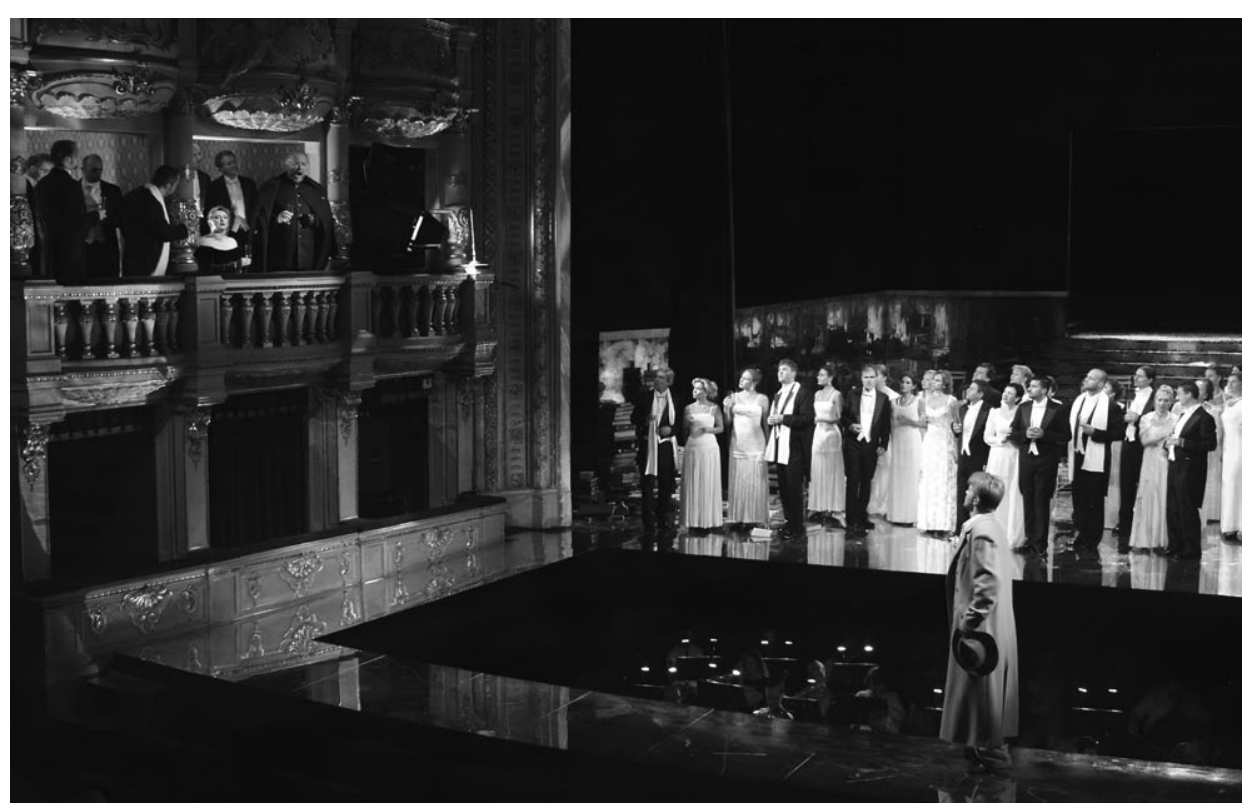

Piotr Iljič Čajkovskij: Eugen Onegin. Slovenské národné divadlo, premiéra 16. 9. 2005. Réžia Peter Konwitschny. Šiesty obraz, ples u Greminovcov. Foto archív SND. Snímka Alena Klenková.

K prelamovaniu tzv. štvrtej steny používa rôzne spôsoby. Najčastejšími sú rozsvecovanie svetla v hl'adisku počas klúčových javiskových výjavov, nadväzovanie kontaktu interpretov s publikom či rozohrávanie dejových situácií uprostred obecenstva. Použité prostriedky evokujú v krajných prípadoch až stratégie imerzného divadla, čo je v opernej inscenačnej praxi stále neobvyklý postup. Inou metódou, prostredníctvom ktorej režisér vytvára emočný odstup od citovo vypätých operných scén, je groteskná štylizácia hereckého výrazu.

\section{Rozsvietené hl’adisko}

Rozsvecovanie priestoru hladiska patrí ku konštantným znakom režisérovho rukopisu. Zmysel scénického prostriedku je zrejmý: publikum, skryté v diskrétnom prítmí, sa nemá neužitočne dojímat' nad opernými príbehmi, ale je vyzvané, aby sa stalo spoluzodpovedným účastníkom prezentovanej drámy. Tento znak bol prítomný aj v každej z piatich inscenácií, ktoré Konwitschny vytvoril v rozpätí rokov 2005 - 2018 v Slovenskom národnom divadle v Bratislave. V Eugenovi Oneginovi ${ }^{4}$ sa pri plnom svetle odohrávali oba emocionálne najexponovanejšie výjavy opery: tzv. listová scéna Tatiany v druhom obraze prvého dejstva, kde sa papieru zveruje s l'úbostným nepokojom, čo do jej života vniesol elegantný Onegin, aj monológ Onegina v šiestom obraze tretieho dejstva, ktorý sa z mostíka postaveného pred orchestrálnou jamou vyznal pred publikom, že Tatiana - dnes krásna žena kniežat’a Gremi-

${ }^{4}$ Premiéra remaku inscenácie v SND v roku 2005, pôvodná premiéra v Oper Leipzig v roku 1995. 


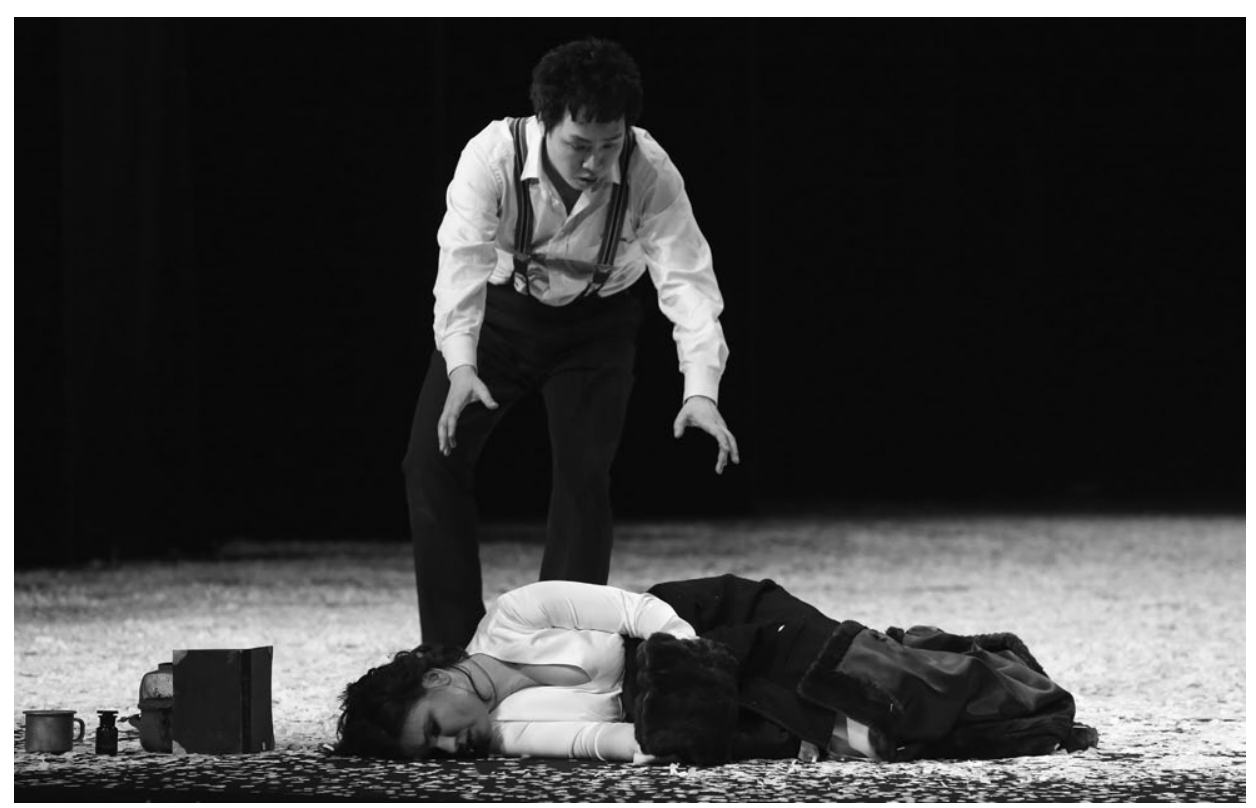

Giacomo Puccini: Bohéma. Slovenské národné divadlo, premiéra 31. 1. 2014. Réžia Peter Konwitschny. Katarína Juhásová (Mimi), Kyungho Kim (Rodolfo). Foto archív SND. Snímka Jozef Barinka.

na - v ňom prebudila dovtedy nepoznanú milostnú vášeň. Svetlá svietili v hl'adisku i počas petrohradského plesu, v ktorom Tatiana s manželom a vyberanou spoločnostou sedeli v krajných lóžach prvého balkóna. Pre slovenské obecenstvo išlo o novú recepčnú skúsenost': po prvý raz v histórii nášho operného divadla mohlo precítit, že svetlo v sále neruší divadelnú ilúziu, ale naopak, pozýva divákov, aby sa stali jej súčastou.

V Pucciniho Bohéme $e^{5}$ Konwitschny aj prostredníctvom práce so svetlom potlačil sentimentálny náter, ktorý na diele spočinul počas jeho viac než storočnej interpretačnej tradície. Inscenáciu vystaval ako sociálne angažované divadelné svedectvo o tom, že na chudobe nie je nič romantického ani vznešeného, a že hoci človek pudovo uteká pred smrtou, od narodenia jej kráča v ústrety. Hladisko rozsvietil v záverečnom obraze, ked’ sa na scénu vracia smrtel’ne chorá Mimi, aby umrela v blízkosti tých, ktorých l’úbi. Operný kritik Vladimír Blaho o tomto okamihu napísal: „Režisérovo obl'úbené rozsvietenie hl'adiska pri príchode umierajúcej Mimi môže byṫ snahou vtiahnut diváka k účasti na prežívaní smrti protagonistky, alebo aj opačne (v brechtovskom duchu), môže fungovat’ ako akýsi odcudzovací efekt, ktorý má zabránit prvoplánovému dojatiu diváka. ${ }^{\prime 6}$

\footnotetext{
${ }^{5}$ Premiéra remaku inscenácie v SND v roku 2014, pôvodná premiéra v Oper Leipzig v roku 1991.

${ }^{6}$ BLAHO, V. Bohéma antisentimentálna? In Monitoring divadiel na Slovensku, 8. 7. 2015. [online]. [cit. 20. 9. 2019]. Dostupné na internete: https://www.monitoringdivadiel.sk/recenzie/recenzia/bohema-antisentimentalna/.
} 


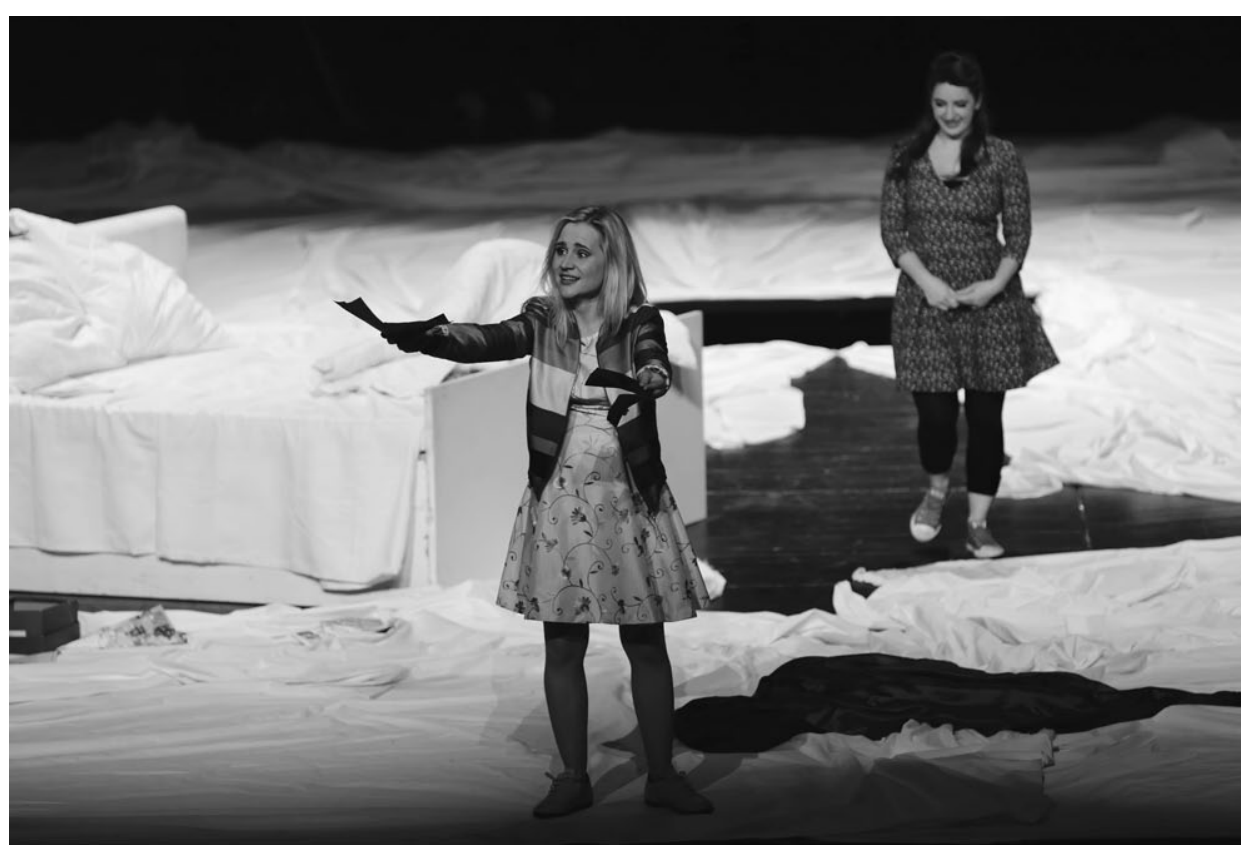

Leoš Janáček: Vec Makropulos. Slovenské národné divadlo, premiéra 6. 11. 2015. Réžia Peter Konwitschny. Linda Ballová (Emilia Marty), Katarína Flórová (Krista). Foto archív SND. Snímka Jozef Barinka.

Podobným spôsobom riešil Konwitschny smrt’ viacerých operných hrdiniek, napríklad japonskej gejše Čo-čo-san z Pucciniho opery Madama Butterfly , páchajúcej samovraždu pred zrakmi publika sediaceho v osvetlenom hladisku, či Violetty z Verdiho opery La traviata ${ }^{8}$, ktorá sa všetkými opustená stratila v černi javiska kontrastujúcej s vysvietenou sálou. Emiliu Marty v Janáčkovej Veci Makropulos ${ }^{9}$ Konwitchny umriet' nenechal - smrt' v podobe prízraku mladého Janka, ktorý z neopätovanej lásky k nej spáchal samovraždu, sa jej len nežne dotkla -, no v hladisku sa aj tak rozsvietilo a diváci boli vystavení pokušeniu. Emilia im ponúkala recept na elixír večnej mladosti: „Já už to nechci! Zde, vemte si to. Nikdo to nechce?“ Ked” jej výzva ostala bez odozvy, spoločne s Kristou recept spopolnili a potom s kuframi v rukách odišli cez zadný technický vchod do bratislavských ulíc za skutočným, smrtel'ným životom. Podobné riešenie Konwitschny už predtým použil vo Verdiho Aide ${ }^{10}$. Záverečný duet Aidy a Radamesa sa má odohrávat’ v podzemnej hrobke, kde sú milenci zaživa pochovaní. No Verdi, ako argumentuje Konwitschny, pre tento hrôzostrašný moment neskomponoval tragické číslo, ale „čarovne nebeskú hud-

\footnotetext{
${ }^{7}$ Premiéra remaku inscenácie v SND 2007, pôvodná premiéra v Oper Graz v roku 1992.

${ }^{8}$ Inscenácia mala pôvodnú premiéru v Oper Graz v roku 2011, neskôr ju uviedli aj Oper Nürnberg, English National Opera a Theater an der Wien.

${ }^{9}$ Janáčkova Vec Makropulos bola jedinou spomedzi bratislavských inscenácií Petra Konwitschného, ktorá vznikla pôvodne pre SND, premiéra v roku 2015.

${ }^{10}$ Premiéra v Oper Graz v roku 1994.
} 


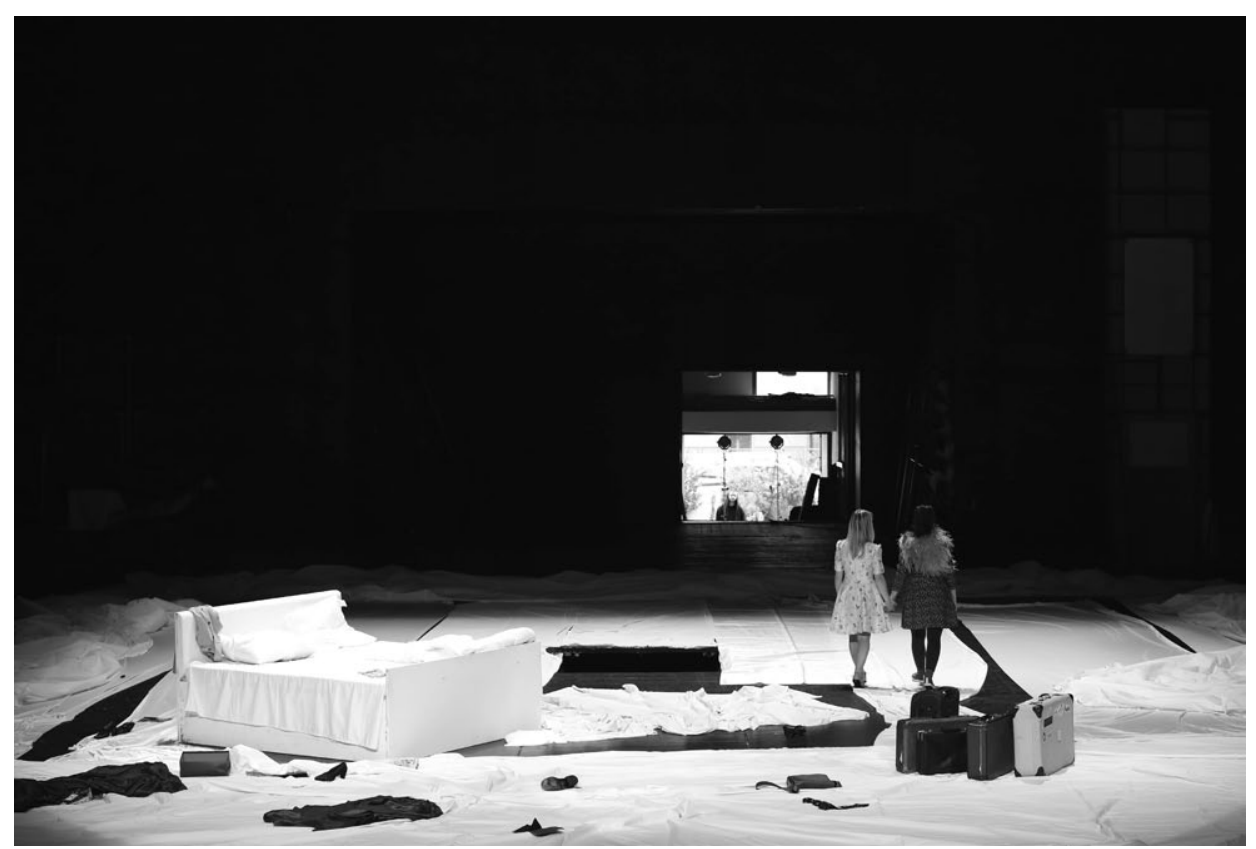

Leoš Janáček: Vec Makropulos. Slovenské národné divadlo, premiéra 6. 11. 2015. Réžia Peter Konwitschny. Záverečná scéna. Foto archív SND. Snímka Jozef Barinka.

bu“. ${ }^{11}$ Tú režisér pretavil do riešenia, ktoré nazval „utópiou“: milenci neumierajú, ale cez otvorenú zadnú stenu javiska odchádzajú von z divadla, ,jednoducho kamsi preč z operného sveta“. ${ }^{12}$ Podobnou variáciou na „utópiu“ bola aj smrt’ Tristana a Izoldy v mníchovskej inscenácii Wagnerovho diela. ${ }^{13}$ Mŕtvi milenci so záverečnými taktami opery spoločne zatvorili oponu antiiluzívne riešeného javiska a opustili scénu, zatial' čo Izoldina priatel'ka Brangäne a Tristanov otec, král' Marke, ostali smútit’ pri bielych rakvách. ${ }^{14}$

Spomedzi piatich Konwitschného inscenácií uvedených v SND bol princíp využívania svetla ako aktivizačného momentu najintenzívnejšie prítomný v Halévyho Židovke. ${ }^{15} \mathrm{~V}$ hl'adisku sa svietilo počas najkrajších hudobných čísiel opery - pri árii Rachel Il va venir, v ktorej sa vyznáva zo svojich obáv a výčitiek pre tajný milostný vztłah s krestanom Léopoldom, aj pri árii Rachelinho domnelého otca Éléazara Rachel, quand du Seigneur la grâce tutélaire, ozrejmujúcej jeho pocity viny za blížiacu sa Rachelinu smrt', ktorej pre svoju pýchu a túžbu pomstitł sa skutočnému otcovi

${ }^{11}$ KONWITSCHNY, P. Aida II. Frauen, Tod, Oper. In WELKER, Andrea (ed.). Peter Konwitschny. „Mensch, Mensch, Mensch!" Oper als Zentrum der Gegenwart, s. 248.

${ }^{12}$ KONWITSCHNY, P. - KÄMPFER, F. Körper, Tod un Utopie. [rozhovor]. In WELKER, Andrea (ed.). Peter Konwitschny. "Mensch, Mensch, Mensch!“ Oper als Zentrum der Gegenwart, s. 191.

${ }^{13}$ Premiéra v Bayerische Staatsoper, 1998.

${ }^{14}$ Viac k analýze inscenácie pozri BAYER, Robert. Konwitschného Tristan a Izolda na doskách Bavorskej štátnej opery. In SPURNÁ, Helena (ed.). Hudební divadlo jako výzva. Praha : Národní divadlo, 2004.

${ }^{15}$ Premiéra remaku inscenácie v SND v roku 2017, pôvodná premiéra vo Vlaamse Opera Antwerpen/ Gent v roku 2015. 


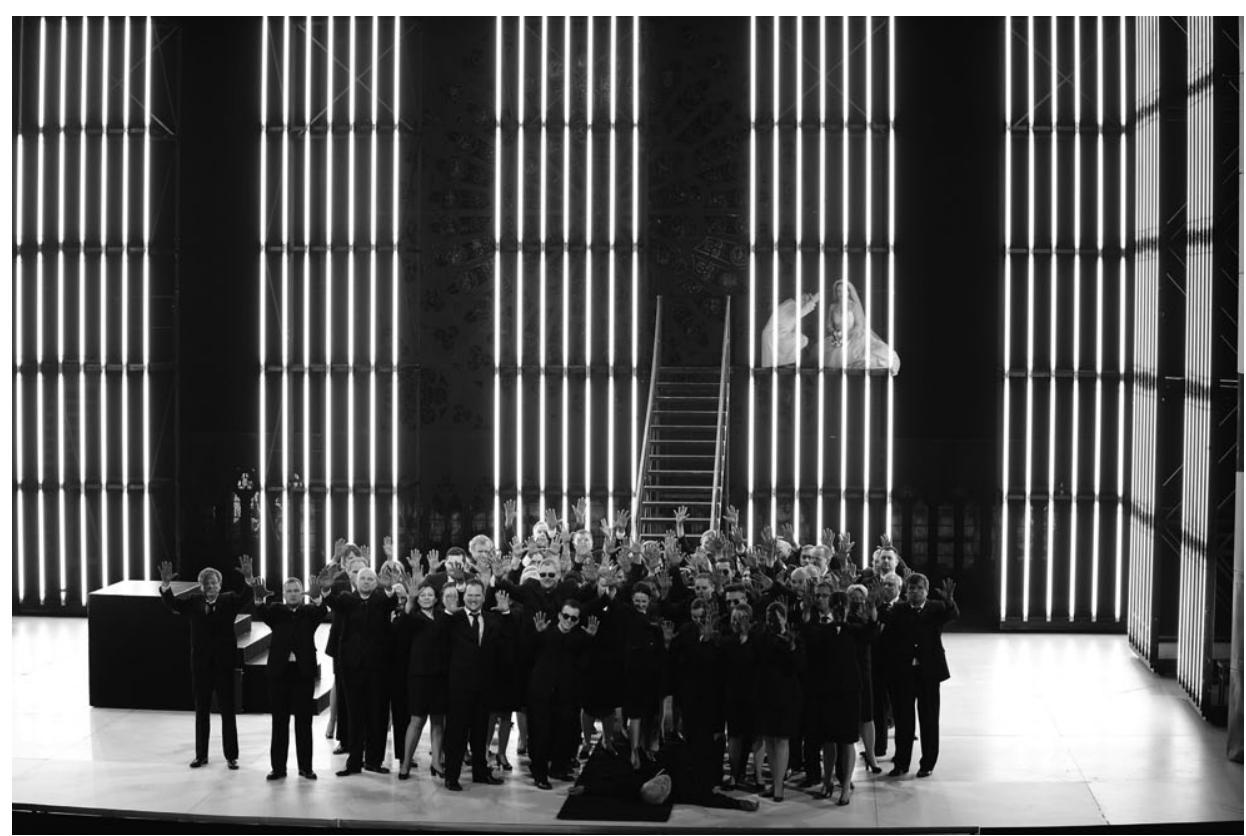

Jacques Fromental Halévy: Židovka. Slovenské národné divadlo, premiéra 7. 4. 2017. Réžia Peter Konwitschny. Zbor Opery SND. Foto archív SND. Snímka Pavol Breier.

Rachel, kardinálovi Brognimu, nedokáže zabránit. Obe árie sa v tejto podobe stali verejnými spoved’ami operných hrdinov, ked’že rozsvietené javisko ich pripravilo o anonymizujúcu intimitu. Diváci/poslucháči si nesmeli nerušene vychutnat ani prekrásnu orchestrálnu medzihru. Orchester ju síce zahral koncertne, t. j. pri zatiahnutej opone, ale režisér pri tom do hladiska namieril viacbodový reflektor umiestnený nad orchestriskom.

\section{Od hercov v hl'adisku k postupom imerzného divadla}

Súčasne s rozsvietením sály Konwitschny často presúva dej z javiska do hladiska. Niekedy sú to iba nástupy či odchody protagonistov, bežné aj u iných režisérov (napr. konzul Sharples v Madama Butterfly vystupujúci na javisko z orchestriska), no zväčša má umiestnenie diania medzi divákov významnejšiu, pointujúcu funkciu. V záverečnom obraze opery La traviata, ked’ bolo zrejmé, že ani Violettino odhodlanie žit’ nepremôže blížiacu sa smrt', nechal Konwitschny Alfreda zbabelo preliezt’ cez krajnú lóžu a obrubu orchestrálnej jamy do vysvieteného hl'adiska, kde ho už čakal otec Giorgio Germont v sprievode slúžky Anniny a doktora Grenvila, zatial' čo sa všetkými opustená Violetta vizuálne „utopila“ v čiernych útrobách scény. Režisér tak vstúpil do svedomia dnešnému svetu, v ktorom väčšina umierajúcich odchádza zo života bez opory vo svojich najbližších. Aj od Emilie Marty (u Janáčka umierajúcej, u Konwitschného len vysilenej výsluchom a premoženej alkoholom) mužskí protagonisti zbabelo utiekli do hl'adiska, aby tam vydesení dekonštrukciou scény (t. j. ich sveta) hl'adali záštitu u d’alších členov mužského zboru. Toto komicky pôsobiace 


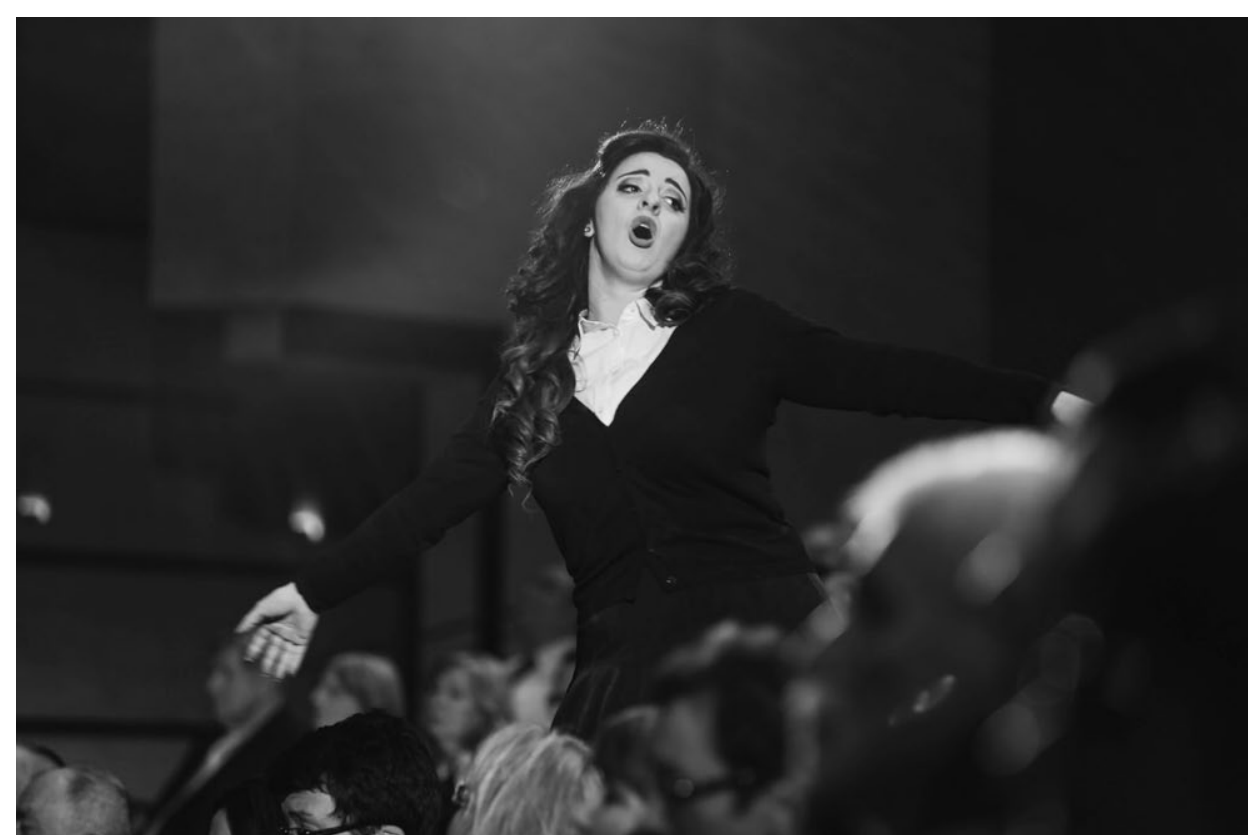

Jacques Fromental Halévy: Židovka. Slovenské národné divadlo, premiéra 7. 4. 2017. Réžia Peter Konwitschny. Katarína Flórová (Rachel). Foto archív SND. Snímka Pavol Breier.

gesto interpretoval operný kritik Pavel Unger v súlade s režisérovým svetonázorom ako „koniec patriarchátu“"16.

V kontexte bratislavskej misie Petra Konwitschného bolo prepojenie javiska s hladiskom najintenzívnejšie opät’ v Halévyho Židovke. Ako sa režisér vyjadril v jednom z rozhovorov, „otvorením štvrtej steny chceme dosiahnut to, aby divák nesledoval predstavenie len pasívne, ale intenzívnejšie pocítil, aký je príbeh vážny a krutý. Účelom je tiež podráždit’ ho a vyprovokovat', niečo v zmysle, som tu teda divákom či účinkujúcim, a kde je vlastne javisko?’ Chceme, aby vyšiel zo svojho stuhnutého absolutistického spôsobu myslenia. ${ }^{\text {17 }}$

Publikum najprv vtiahol do centra diania pri konflikte milencov, židovky Rachel a krestana Léopolda. Ked' sa princ priznal k pravej konfesii, interpretka v improvizovanej slovenskej próze ${ }^{18}$ posmešne komentovala jeho citový výlev, prihovárajúc sa obecenstvu zo širokej uličky medzi dvomi radmi sedadiel, ktorou rozčúlene pobehovala: „Ó, tenor spieva áriu! Aj ten váš doma to tak zvykne?"

${ }^{16}$ UNGER, P. Janáčkov návrat s Konwitschného puncom. In Pravda, roč. 25, č. 261, s. 3, 11. 11. 2015.

${ }^{17}$ KONWITSCHNY, P. - VONGREJ, L. Príbeh Zidovky nás učí, že musíme prestat s násilím a hl'adat’ viac lásky. [rozhovor]. In Operaslovakia.sk, 7. 4. 2017. [online]. [cit. 22. 9. 2019]. Dostupné na internete: https:// operaslovakia.sk/peter-konwitschny-pribeh-zidovky-nas-uci-ze-musime-prestat-s-nasilim-a-hladat-viac-lasky/, 7. 4. 2017.

${ }^{18}$ Opera bola naštudovaná v originálnom francúzskom jazyku libreta. 
Ešte hlbšie do intímneho priestoru divákov prenikol zbor roztrúsený v hladisku, hlučne mávajúci papierovými zástavkami a rehotajúci sa na kvartete Rachel, Éléazara, Léopolda a Ruggiera De ces nobles guerriers, ktorý sa v grotesknej hereckej hyperbole odohrával na javisku. Nastal tu efekt prítomný v imerzných typoch predstavení: divák pozoroval zboristov vo svojej blízkosti, a zároveň sa cítil byt nimi pozorovaný pri vlastných reakciách. Pre slovenské operné publikum, zvyknuté na iluzívnu divadelnú poetiku, išlo o principiálne novú situáciu. Toto - mnohým návštevníkom predstavení akiste nepríjemné inscenačné riešenie - Konwitschny zdôvodnil hudobne podloženými argumentmi. V menovanom kvartete skomponoval Halévy lahkú, chvíl'ami až operetne banálnu hudbu ${ }^{19}$, čo režisér pohotovo využil pre popísaný scudzovací moment.

V tomto zmysle je referenčnou prácou inscenácia pätdejstvovej francúzskej verzie Verdiho Dona Carlosa ${ }^{20}$, konkrétne spôsob, akým Konwitschny vyriešil tzv. autodafé21 situované v druhej časti tretieho dejstva. Medzi dvoranov vtedy prichádza král'ovský sprievod na čele s Filipom II., ktorý slubuje ochránit’ svoj l'ud ohňom a mečom. Zatial' čo Španieli vzdávajú hold panovníkovi, mnísi odvádzajú heretikov na popravisko. Král’ov syn Don Carlos žiada Filipa o slobodu pre zotročených Flámov, no otec jeho prosbu odmieta. Hranica sa zapal'uje a spoza scény zaznieva nebeský hlas, zvestujúci odsúdencom večný mier.

V Konwitschného inscenácii sa autodafé začínalo počas prestávky vo foyeri divadla. Televízna komentátorka prostredníctvom reproduktorov euforicky oznámila divákom, že Viedenskú štátnu operu poctí návštevou španielsky král’ s manželkou a pozvala ich sledovat' príchod vzácnych hostí na schodisku vo foyeri, prípadne na televíznych obrazovkách vnútri sály, kam sa prostredníctvom kamier prenášalo dianie z exteriérových priestorov. Oslavujúci zbor začal spievat’ na javisku ešte počas návratu divákov z prestávky, čím prekvapil najmä tých, ktorí ostali sediet’ dnu. Radostné očakávanie prominentných hostí skalil pohlad na väzňov inkvizície: zviazaní a bití obuškami prešli najprv schodiskom, potom javiskom a nakoniec ich trýznitelia vyviedli von opät’ cez hl'adisko. Boli to rovnakí muži ako tí na javisku, len mali vyzlečené saká a biele košele sa im zašpinili od krvi. Královský sprievod medzitým prešiel hlavným schodiskom a vstúpil do sály. Príhovor Filipa II. zaznel medzi divákmi, až potom protagonisti vkročili na javisko, sprevádzaní bleskami fotoaparátov a sledovaní televíznymi kamerami. Don Carlos teda obvinil Filipa zo zločinov proti Flámom v priamom televíznom prenose. Fotografie týraných l'udí rozdával zboristom na scéne a súčasne ich ponúkali aj štatisti divákom v hl’adisku. Mimojaviskovú postavu Nebeského hlasu zo záveru autodafé nahradil Konwitschny speváčkou s výzorom Marilyn Monroe, ktorá zvodným vystúpením uprostred pódia odvracala pozornost’ od fotografií vojnových zločinov, premietaných na obrazovke za jej chrbtom.

\footnotetext{
${ }^{19}$ Autor bratislavského hudobného naštudovania, hostujúci český dirigent Robert Jindra, vyslovil v predpremiérovom rozhovore domnienku, že „možno Halévyho ideou bolo zdôraznit aj cynickú stránku celého tragického príbehu“. Pozri JINDRA, R. - KMEČOVÁ, V. Halévyho Židovka ako predzvest' Gesamtkunstwerku. [rozhovor]. In Operaslovakia.sk, 6. 4. 2017. [online]. [cit. 21. 9. 2019]. Dostupné na internete: http://operaslovakia.sk/robert-jindra-halevyho-zidovka-ako-predzvest-gesamtkunstwerku/.

${ }^{20}$ Inscenácia mala pôvodnú premiéru v Staatsoper Hamburg v roku 2001, v európskom operno-divadelnom kontexte však väčšmi zarezonoval jej remake vo Wiener Staatsoper, premiéra v roku 2004.

${ }^{21}$ Autodafé bol slávnostný akt vyhlásenia inkvizičného rozsudku nad kacírom alebo odpadlíkom od viery.
} 


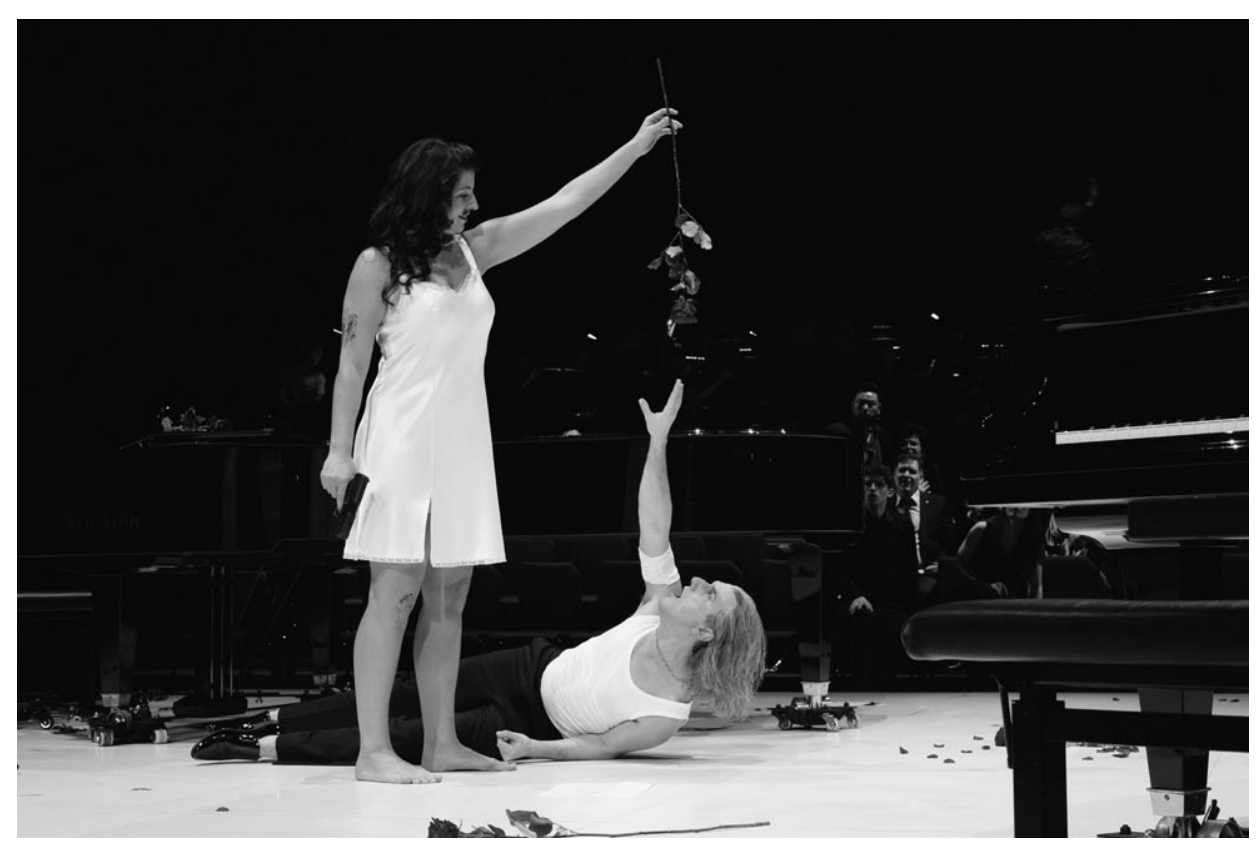

Othmar Schoeck: Penthesilea. Landestheater Linz, premiéra 2. 3. 2019. Réžia Peter Konwitschny. Dshamilja Kaiser (Penthesilea), Martin Achrainer (Achilles). Foto @ Reinhard Winkler / Landestheater Linz.

Don Carlos sa v čase viedenského uvedenia vnímal ako mimoriadne kontroverzná inscenácia, a to aj v kontexte divadelne nekonvenčnej tvorby Petra Konwitschného. Premiérové publikum reagovalo búrlivo, pri klaňačke sa rozpútal verbálny boj medzi frakciami divákov kričiacimi „Buh!“ a „Bravo!“. Po opadnutí vášní sa táto inscenácia zaradila k najoceňovanejším režisérovým prácam a na viedenskú scénu sa o osem rokov vrátila v novom hudobnom naštudovaní. Slovami Ioana Holendera, dlhoročného riaditel’a Viedenskej štátnej opery (1992 - 2010), „Don Carlos bol pri svojej premiére obrovským diváckym škandálom, no postupom času sa z neho vyvinula pravá kultová produkcia“22.

V súčasnosti sa už prepájanie javiska s hl'adiskom považuje za organickú súčast’ rukopisu Petra Konwitschného, s ktorou publikum (resp. jeho informovaná čast') počíta. V jednej z najnovších inscenácií, opere Othmara Schoecka Penthesilea ${ }^{23}$, rozohral dej na komornom výseku javiska riešenom ako aréna. Väčšina divákov sedela štandardne $\mathrm{v}$ sále, no asi pät’desiat $\mathrm{z}$ nich zaujalo miesta $\mathrm{v}$ tejto aréne, ohraničenej tromi radmi stoličiek umiestnenými na prekrytom orchestrisku a proscéniu, zatial' čo orchester ostal v priestore za nimi. Režisér zotrel hranicu medzi recipientmi a interpretmi aj na opačnej strane rampy. To, že elegantne oblečené dámy na krajných miestach v hladisku sú Penthesileine spolubojovníčky Prothoe a Meroe, sa dalo pochopit' najneskôr vtedy, ked' sa interpretky postavili a začali hrat'. Rovnako l’ahko sa dalo dešif-

${ }^{22}$ HOLENDER, I. Don Carlos. Publikumsskandal - Kultproduktion. In WELKER, Andrea (ed.). Peter Konwitschny. "Mensch, Mensch, Mensch!“ Oper als Zentrum der Gegenwart, s. 412.

${ }^{23}$ Koprodukčná inscenácia Theater Bonn a Landestheater Linz, premiéra v roku 2017. 
rovat, že prísna dáma v lóži je najvyššia kňažka bohyne Diany. Omnoho tažšie bolo identifikovat', kto z ludí sediacich v aréne na javisku je divák a kto zborista či štatista. Všetci mali civilné oblečenie, takmer všetci držali v rukách bulletiny a každý z nich sa hmýril, ked’ nemal dostatočný výhl’ad na scénickú akciu. Hoci nešlo o imerzný tip divadla, v ktorom sa divák stáva spolutvorcom inscenácie, Konwitschného "fake“ pôsobil vel’mi autenticky. Napríklad pán, ktorý vyzeral ako platiaci návštevník, sa asi v polovici predstavenia obrátil, aby utešil Prothoe plačúcu nad osudom svojej priatel'ky Penthesilei.

K najsugestívnejším, aj ked' vzhl'adom na nedostatočný časový odstup zatial' menej reflektovaným prácam Petra Konwitschného patrí inscenácia opery Die Soldaten. ${ }^{24}$ Rakúsky skladatel' Bernd Alois Zimmermann (1918 - 1970) do diela skomponovaného na námet rovnomennej drámy predstavitel’a hnutia Sturm und Drang Jakoba Lenza premietol traumu z 2. svetovej vojny, ktorú prežil ako frontový vojak. No kým Lenzova dráma sa sústred’uje na tragický príbeh mladého meštiackeho chlapca Stolziusa, ktorý prichádza o snúbenicu, pretože Marie dá prednost' pozornosti šlachtických dôstojníkov, Zimmermann sa zameral na sociálny i ludský pád meštianskej dcéry Marie Wesenerovej, upadajúcej z rozmaznávanej dôstojníckej milenky na armádnu pobehlicu. Hudobná dráma zároveň nesie silné antimilitaristické posolstvo. No blížiaca sa vojnová kataklizma, ktorou Zimmermannov opus vrcholí, nedostala v Konwitschného koncepcii ilustratívne priamočiaru podobu. Namiesto toho vysunul do popredia drámu rozkladajúcich sa morálnych osobných i rodinných hodnôt.

Inscenácia sa začala predohrou, ktorú orchester zahral pri otvorenej opone bez javiskovej akcie, zatial' čo sa diváci pozerali na opustené zostavy perkusií umiestnené na vyvýšených pódiách. S touto vizuálnou podporou si mohli ešte intenzívnejšie uvedomit hudobné zovretie expresívnej partitúry. ${ }^{25}$ Pohladom na prázdne javisko režisér zároveň anticipoval antiiluzívny rozmer inscenácie: prestavby jednotlivých obrazov, ktoré nasledujú v rýchlych sledoch, realizovali štatisti tiež pri otvorenej opone. Zmeny prostredí sa diali spúštaním rôznofarebných zadných stien príslušných dejísk (nevinne zelená pre izbu Wesenerových dcér, Marie a Charlotty, jedovato žltá pre domácnost’ Stolziusa a jeho autoritatívnej matky, agresívne červená pre salón oficiera Maryho).

Rovnako ako je Zimmermannova partitúra vystavaná v dramatickom crescende, tak sa aj Konwitschného koncepcia odvíjala od grotesknej frašky k tragickému finále. V úvode režisér s brechtovským odstupom ironizoval stereotypy a klišé, predstavujúc protagonistov nie ako charaktery, ale ako hyperbolizované typy. O to intenzívnejšie vyznelo jeho riešenie záverečného štvrtého dejstva Zimmermannovej opery, odohrávajúceho sa na pozadí vojnových hrôz. Táto čast’ je zvukovo i sujetovo drastickým vyvrcholením neštastných osudov Stolziusa, ktorý otrávi Mariinho zvodcu Desportesa a následne spácha samovraždu, aj Marie, z ktorej sa po opakovanom znásilnení stáva vyhladnutá prostitútka núkajúca sa za kus chleba. Konwitschny vo svojej inscenácii úplne potlačil sexuálny rozmer a publiku predostrel bol’avú drámu, ktorú ho nechal prežit' doslova na vlastnej koži.

\footnotetext{
${ }^{24}$ Inscenácia Opernhaus Nürnberg, premiéra v roku 2018.

${ }^{25}$ Pôvodne plánovaná premiéra opery, ktorú si od B. A. Zimmermanna objednala opera v Kolíne nad Rýnom (1963), bola zrušená z dôvodu nehratel’nosti diela. Skladatel’ partitúru čiastočne zrevidoval, svetová premiéra sa v Kolíne nad Rýnom konala o dva roky neskôr.
} 


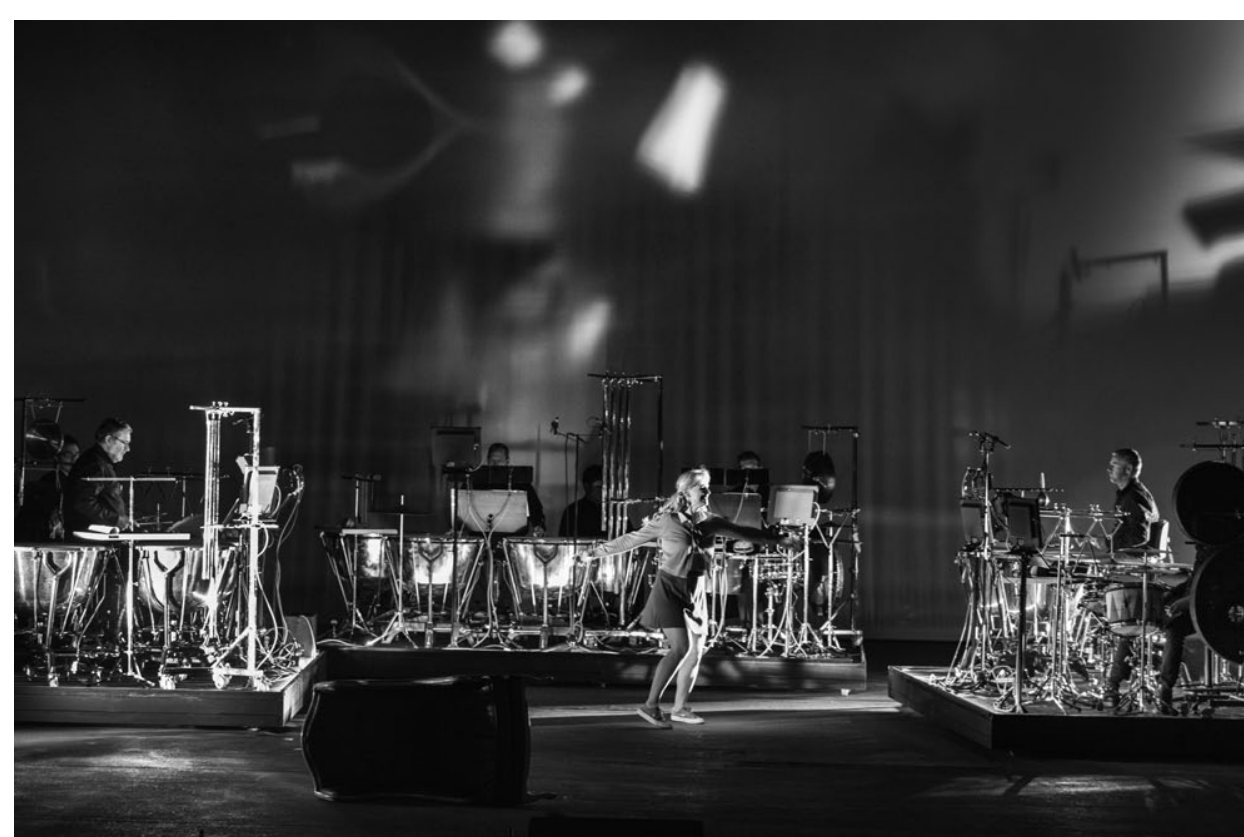

Bernd Alois Zimmermann: Die Soldaten. Staatstheater Nürnberg, premiéra 17. 3. 2018. Réžia Peter Konwitschny. Susanne Elmark (Marie). Foto @ Ludwig Olah / Staatstheater Nürnberg.

Po skončení prestávky pred štvrtým dejstvom boli všetci diváci presmerovaní na javisko, kde ich, natlačených na malom priestore a uzavretých železnou oponou, atakovala kataklizmatická Zimmermannova hudba. Protagonisti opery rozostavení na balkóne nad úrovňou javiska podali informácie o otrasných udalostiach sprevádzajúcich Mariin pád, skomprimované do vecnej prozaickej formy (v originálnej partitúre ide o spievanú dramatickú pasáž), a po tomto epickom referáte sa opona otvorila. V centrálnej lóži prázdneho hl'adiska sa odohrávala dôstojnícka večera. Počas nej Desportes cynicky rozprával priatel'ovi Marymu o tom, ako Marie, ktorej sa už presýtil, podhodil svojim vojakom. Jeho vulgárne vystatovanie sa stalo obraznou poslednou kvapkou do Stolziovho kalichu trpkosti. Vel'kým teatrálnym gestom nabral obom mužom polievku, do Desportesovho taniera okázalo nasypal jed a v následnej bitke zabil Maryho. Zámernou hyperbolizovanou grotesknostou scény sa režisérovi paradoxne podarilo dosiahnut silný emocionálny účinok: po smrti mužov, čo mu strpčovali život, Stolzius vytiahol spoza sedadiel svojho bábkového dvojníka v životnej vel'kosti, s uboleným pohl'adom sa mu vyžaloval a prehodil ho cez zábradlie.

Po jeho čine sa na javisku pomedzi divákov začala predierat’ strapatá žena v špinavých šatách, civilným hlasom prosiaca o almužnu, pretože tri dni nemala nič v ústach. Práve v tejto mizanscéne sa Peter Konwitschny dostal na bezprostrednú hranicu medzi iluzívnym a imerzným divadlom. Hoci bez predchádzajúceho upovedomenia, diváci boli prizvaní, aby sa stali nielen priamymi účastníkmi, ale aj spolutvorcami drámy: aby sa cítili trápne, aby odvracali zrak od herečky, uvedomujúc si, kol'kokrát sa s podobnou situáciou stretli v reálnom živote. Jeden z mužov sa na ženu hrubo osopil a zahnal ju. Bol to pán Wesener, nespoznávajúci v zúboženej chudere 


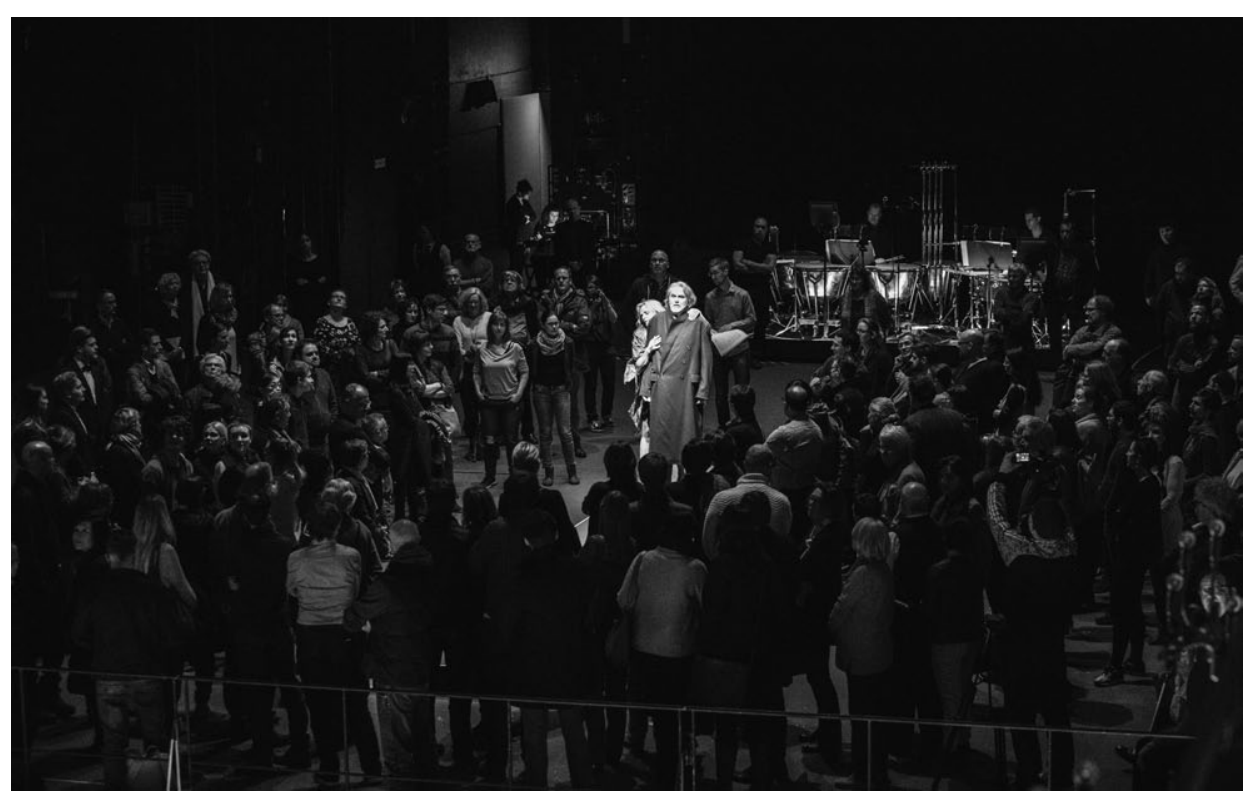

Zimmermann: Die Soldaten. Staatstheater Nürnberg, premiéra 17. 3. 2018. Réžia Peter Konwitschny. Záverečná scéna. Susanne Elmark (Marie), Tillmann Rönnebeck (Wesener). Foto @ Ludwig Olah / Staatstheater Nürnberg.

dcéru, ktorú zúfalo hl’adal : „Ktovie, kde takto žobre moja Marie...“ Zvuk orchestra sa stiahol do dlhého kvílivého tónu a na bočných obrazovkách, kde sa dovtedy premietali titulky, sa ukázal echogram srdca končiaci dlhou súvislou čiarou, oznamujúci exitus. Divák si mohol klást’ otázku, koho je to smrt': Marie? Stolziusa? Empatie? L'udskosti?

\section{Groteskný odstup}

Finále opery Die Soldaten by pravdepodobne nemalo takú dramatickú emocionálnu razanciu, ak by mu nepredchádzal popísaný tragikomický výjav vrcholiaci smrtou Stolziusa. Portugalský muzikológ Mário Vieira de Carvalho v texte charakterizujúcom Konwitschného rukopis hovorí o cennom výsledku „paradoxného prepletenia“ epického princípu s aristotelovskou katarziou: „Ako reaktivovaná skúsenost” tu však už nevystupuje katarzia v zmysle klamlivého či emocionálneho divadla, ktoré kritizoval Brecht, ale $\mathrm{v}$ pôvodnom zmysle: divadlo ako politikum. Patrí do sféry étosu, nie pátosu. $\mathrm{V}$ tom istom zmysle funguje aj d’alšia dimenzia odcudzovacieho princípu v Konwitschného inscenáciách: smiech, ktorý oslobodzuje. To, čo sa považuje za zjavné, samozrejmé a spol’ahlivé, sa u neho rozpustí v karikatúre. Odhalenie, že čosi údajne zmysluplné je v skutočnosti nezmyslom, je spúštačom smiechu. ${ }^{26}$

${ }^{26}$ CARVALHO, M. V. Die Überlieferung dem Konformismus abgewinnen. In WELKER, Andrea (ed.). Peter Konwitschny. "Mensch, Mensch, Mensch!“" Oper als Zentrum der Gegenwart, s. 152. 


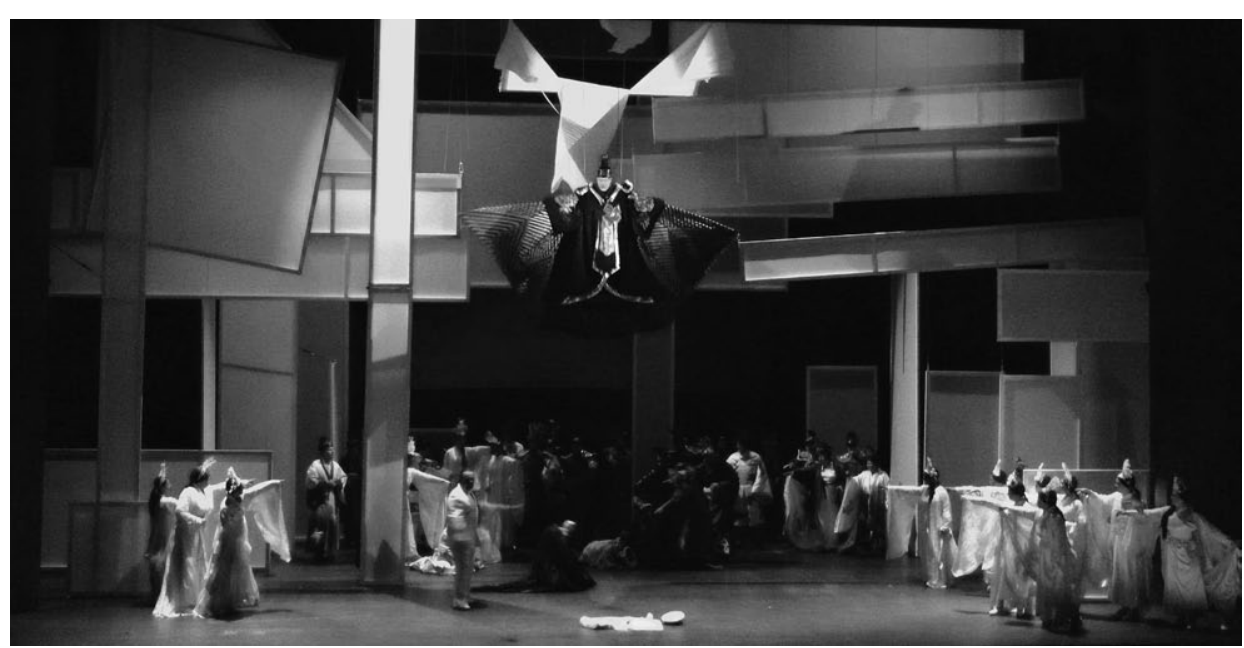

Giacomo Puccini: Madama Butterfly. Slovenské národné divadlo, premiéra 5. 10. 2007. Réžia Peter Konwitschny. Ján Galla (Bonzo). Foto archív SND. Snímka Alena Klenková.

Tento princíp využíva Peter Konwitschny vo svojich inscenáciách často a v rôznom rozsahu. Niekedy mu dáva len formu drobného skeču, v ktorom karikuje spoločenský femonén zastúpený konkrétnou postavou. Napríklad v Madama Butterfly, vystavanej ako psychologická rodinná dráma, dostal strýko Bonzo zosobňujúci patriarchálnu nadvládu aj upäté spoločenské konvencie podobu barokového deus ex machina. Zniesol sa z horného povraziska zavesený na t’ahoch a komicky mávajúc dlhočiznými rukávmi ako krídlami preklínal Čo-čo-san, ktorá zradila svoj rod, pričom obrazne i fyzicky rozbíjal gýčovitú idylu paravánových domčekov. Legendárna scéna v Aide, kde sa Radames vrátil z boja v zakrvavenej uniforme a v ruke držal roztrhaného plyšového slona, čo mu darovala Amneris, vyznela v kontexte inscenačnej tradície až blasfemicky: ironizovala opulentnost’ výtvarných riešení Verdiho diela, a zároveň reflektovala Radamesovu nevinnost' prehratú vo vojne. Podobne pôsobilo aj aranžmán Liebesduettu v mníchovskej inscenácii Wagnerovej opery Tristan a Izolda (1998), kde sa milenci počas hudobne vznešeného, až patetického čísla obhadzovali vankúšmi ako malé deti. Vo Veci Makropulos zase vytvárali odstup od deja textové komentáre premietané na tylovej opone, pričom ich literárny štýl osciloval medzi rozprávkou a komiksom. Do Janáčkovho hudobno-filozofického podobenstva o nezmyselnosti nekončiaceho sa pozemského života tak prenikli prvky odkazujúce skôr ku komediálnemu žánru Čapkovej literárnej predlohy.

Výtvarnú plošnost’ a informačnú priamočiarost' komiksu Konwitschny priamo uplatnil v inscenácii ranej opery Giuseppe Verdiho Attila. ${ }^{27}$ Ústredným konfliktom diela odohrávajúceho sa na území Talianska v 5. storočí je stret západnej krestanskej kultúry a barbarských Hunov. Na jeho pozadí sa odvíja príbeh ústredných postáv: odbojnej Odabelly túžiacej zabit vodcu Hunov Atillu a pomstit tak otcovu smrt', aj d’alších potenciálnych vrahov uzurpátora - politicky ambiciózneho rímske-

\footnotetext{
${ }^{27}$ Theater an der Wien, premiéra v roku 2013.
} 
ho generála Ezia a Odabellinho snúbenca Foresta. Konwitschny rozdelil inscenáciu do troch častí. Štyri obrazy tvoriace prológ a prvé dejstvo nazval "Detsky hravi“", druhé dejstvo „Infantilne dospelí“, záverečné tretie malo podtitul „Stále nepoučitelni".

Prvú čast’ situovali inscenátori pred kašírovaný múr, deravý od zásahov prakmi a drevenými mečmi, s ktorými medzi sebou zápasili zboristi preoblečení za deti. Dospelí muži s bojovo pomalovanými tvárami, naháňajúci sa so zbraňami ukoristenými za maminým chrbtom (varešky, metličky, valčeky, panvice, kefy na čistenie toaliet), pôsobili vel'mi komicky, rovnako ako ich vodca Attila stojaci na drevenom vozíčku a vyzbrojený bičíkom vytvoreným z varechy a motúzika. Divoká Odabella hrala na dvojrozmernej papierovej makete gitary, obrázkovo plošné boli aj kulisy stromov na ihrisku. Eziovu zradu Talianska symbolizoval modrý balónik s motívom zemegule, podarovaný Attilovi. Druhý obraz Verdiho opery začínajúci orchestrálnou búrkou sprevádzali rozprávkovo preexponované farebné blesky. Zbor eremitov z tohto dejstva predstavil Konwitschny ako principiálnu absurditu (pustovníci nežijú v skupinách), považujúc ho za prejav Verdiho zmyslu pre humor: stvárnil ich ako groteskné figúrky v bielych rúchach, s dlhými bradami z pletacej vlny, ktoré obdivovali papierové lodičky plávajúce proscéniom. Výjav, kde sa Foresto pokúsi zavraždit Attilu otráveným vínom a Odabella sa mu v tom snaží zabránit, pretože pomstu Attilovi považuje za svoje osobné právo, komentoval režisér bublinkami so stručnými textami („Attila, moja ponuka stále plati'“, „Nikdy, úbohý Riman!“, „Môj jed mu bude chutit", „Polapí nás temnota“ a pod.). Charakteristický prostriedok komiksu prispel k sprehl'adneniu dejovo chaotickej situácie a zároveň podčiarkol opernú klišéovitost’ mizanscény.

Finále inscenácie situoval režisér do domova dôchodcov, kde starí, nevládni protagonisti inscenácie prežívali posledné chvíle a bojovali posledné súkromné vojny. Konečný zápas sa odohral na invalidných vozíkoch a rolátoroch. Ezio s Forestom sa snažili zbavit’ Attilu rovnováhy a tahali mu z rúk palice. Prv, než ho nimi stihli utíct', Odabella vytiahla z kufríka nôž, čo jej v prvom obraze venoval Attila. No pomstu, ku ktorej sa celý večer odhodlávala, už nebola schopná vykonat', pretože z vozíčka na ležiaceho Attilu nedosiahla. S poslednými tónmi opery umreli všetci starci prirodzenou smrtou, len Odabella ako metronóm švihala nožom do prázdna.

Viackrát spomenuté brechtovské zázemie Konwitschného divadelnej poetiky sa najzjavnejším spôsobom odrazilo v dvoch inscenáciách diel z oblasti tzv. klasiky 20. storočia - opier Albana Berga Wozzeck ${ }^{28}$ a Dmitrija Šostakoviča Lady Macbeth $z$ mcenského újazdu ${ }^{29}$. Konwitschného koncepcia Wozzecka v čase premiéry zarezonovala ako nevšedný experiment. Nie však pre vybičovanú expresívnost̉ javiskových prostriedkov, ktorou inscenátori Bergovho sociálno-kritického opusu obvykle nešetria, ale pre prekvapivý výtvarný a herecký asketizmus. Na prázdnej scéne pripomínajúcej bielu škatulu spievali muži vo frakoch a ženy v cudných, dlhých čiernych šatách antického strihu. Hrdinovia polokoncertnej inscenácie nemali žiadne vonkajšie znaky odlišujúce ich sociálny status: boli uniformovanou masou, ktorú spájal a zároveň rozdel’oval vztah k bankovkám ostinátne zasýpajúcim prázdne javisko. Absencia rekvizít a kulís tu mala demonštratívne opodstatnenie: výprava k inscená-

\footnotetext{
${ }^{28}$ Staatsoper Hamburg, premiéra v roku 1998.

${ }^{29}$ Koprodukčná inscenácia Kongelige Teater Copenhagen a Theater Augsburg, premiéra v roku 2014.
} 
cii o materiálnej biede nemôže podl’a režiséra stát viac, než by Wozzeck zarobil za celý život.

I v tejto inscenácii boli prítomné vyššie popísané znaky režisérovho rukopisu: rozsvecovanie svetla $\mathrm{v}$ hl'adisku, vystupovanie postáv z rol, ich obracanie sa na divákov. Viaceré mizanscény sa odohrávali v pantomimickej štylizácii, odkazujúcej na gesticky hypertrofovanú poetiku nemého filmu dvadsiatych rokov minulého storočia. Napríklad Marie, opustená dôstojníkom, ktorého zvodom podlahla, si zhnusene utrela ústa, hoci na ne nedostala žiadny bozk, a potom si v imaginárnom zrkadielku, čo vzniklo z jej dlane, obzerala neexistujúce utŕžené náušnice. Nechýbal ani komický skeč, vnášajúci do odohrávajúcej sa tragédie rozrušujúci groteskný tón. Wozzeckovu smrt’ nemali diváci možnost’ sledovat’ na vlastné oči, pretože opona sa v tej chvíli zatiahla. V sále sa rozsvietilo a Doktor s Hauptmannom, stojaci na proscéniu pred oponou, zvedavo nakúkali za záves a citujúc libreto opery informovali publikum o tom, čo vidia na javisku.

Podobnú, no v kontexte inscenácie ešte krutejšiu mizanscénu, exponoval Konwitschny v Šostakovičovej Lady Macbeth. V dokomponovanom činohernom intermezze, pripomínajúcom komické vsuvky v barokových tragických operách, dal pointu predchádzajúcemu výjavu z konca tretieho dejstva. Policajný náčelník, ktorý predtým pokropil svadobných hostí spŕškou zo samopalu, nechal odviesť ženícha Sergeja a znásilnil zatýkanú Katarínu Izmajlovovú, teraz pri rozsvietenom hladisku „priatel’sky“ skúšal publikum, kohože mu s nalepenými fúzami pripomína. Kým si sám so smiechom odpovedal, že Josifa Vissarionoviča Stalina, imaginárne vystriel’al prvé rady obecenstva.

Groteskne štylizovaná inscenácia Šostakovičovej opery patrí v kontexte Konwitschného tvorby $\mathrm{k}$ tým prácam, $\mathrm{v}$ ktorých najkonzekventnejšie a najpriznanejšie čerpal z odkazu Bertolta Brechta. V odpudivom, od vrchu po spodok nabielo vykachličkovanom prázdnom priestore pripomínajúcom márnicu nebolo nič skutočné a stabilné. O nikoho a o nič sa nedalo opriet', rekvizity i osoby privážal a odvážal pohyblivý pás. S atmosférou zbavenou života korešpondovali uniformné kostýmy zboristov, ladené v „špinavej“, bielo-sivo-čiernej farebnosti. Z bezmenného davu opticky vystupovali farebne hyperbolizovaní protagonisti: Katarína v žltej parochni a krikl’avých svadobných šatách (kanáriková žlt’ evokovala vtáčika v klietke), jej sadistický svokor Boris Izmajlov v agresívne červenom obleku, submisívny manžel Zinovij v ostro zelenom kostýme (jeho nemohúcost’ podčiarkoval zženštilý plavý účes), Katarínin neempatický, maskulínny milenec Sergej oblečený do král'ovskej modrej. Nerealistická farebnost’ akcentovala odl'udštenost' a bizarnost' postáv, ktoré sa pohybovali v hyperbolizovanom kŕči antipsychologického herectva. Vyššie popísané činoherné intermezzo nebolo jediným groteskne komponovaným výjavom v opere, podobný herecký slovník použil režisér napr. pri Kataríninej rozlúčke s odchádzajúcim manželom Zinovijom (zamávala mu žltými nohavičkami vytiahnutými spod dlhej sukne), aj pri zavraždení Borisa Izmajlovova (Katarína mu s klaunským úškrnom nasypala do dusených hríbov otravu na potkany po tom, čo publiku kabaretným gestom predviedla obrovské červené vrecko s jedom). Až v záverečnom dejstve, ked’ si Katarína počas cesty do sibírskeho vyhnanstva siaha na život, lebo stratila nádej na Sergejovu lásku, Konwitschny v súlade s humanistickým nervom Šostakovičovej hudby priznal inscenácii tragický rozmer a grotesknost’ potlačil do úzadia. No ako upozornil operný kritik Robert Bayer, „tragédia si pritom aj v po- 
slednom obraze uchováva istú komickoste. Videoprojekcia atómového hríbu je totiž asociatívnym rekurzom na zábery rastúcej muchotrávky v pozadí scény, počas ktorej Katerina otrávila dotieravého Borisa. ${ }^{\text {30 }}$

\section{Záver}

Postoj k vztahu inscenátor verzus divák prezentoval Peter Konwitschny v rozhovore s lipským novinárom Ingolfom Rosendahlom: „Nie som zástancom inscenácií, ktorým rozumejú len špecialisti. Ale to, že sa niečo publiku príliš zadiera pod kožu, nepredstavuje pre mňa dôvod, aby som to menil. Inscenácia môže byt’ autentická iba vtedy, ak stále nemyslím na iných l’udí. “31 Úprimnost’ Konwitschného vyjadrenia dokumentuje nielen divadelná poetika desiatok inscenácií, ktoré od začiatku profesionálnej činnosti (1969) až dodnes vytvoril, ale tiež množstvo konfliktov sprevádzajúcich jeho prácu. Niektoré sa týkali interakcií s publikom ${ }^{32}$, d’alšie jeho komunikácie s vedením divadiel ${ }^{33}$, iné problematickej spolupráce nekompromisného, výbušného tvorcu s interpretmi ${ }^{34}$. Komplikovaný proces vzniku a kontroverzná recepcia viacerých inscenácií však nezmenšujú podiel Petra Konwitschného na podobe moderného európskeho operného divadla. Slovami holandského muzikológa Sebastiana Smallshawa, „Konwitschny je osviežujúcim radikálnym hlasom v systéme, v ktorom sú mnohí režiséri bud’ hanebne spiatočnícki, alebo beznádejne priemerní. ${ }^{35}$

\section{DIRECTOR PETER KONWITSCHNY‘S ART MARCH AGAINST „DEAD OPERA“}

\section{Michaela MOJŽIŠOVÁ}

The text deals with selected principles of the work of the German opera director Peter Konwitschny (1945). The lifelong ambition of an artist who openly proclaims a left-wing orientation is to distract the audience from consuming indulgence in beautiful music and make them a socially responsible, thoughtful participant in his productions. He has created, during his half-century career, a stable database of isotopes through which he fulfils his ideas, from curtain up in the auditorium to solutions resembling immersive theatre strategies. The author presents examples from several

${ }^{30}$ BAYER, R. Konwitschny ženám rozumie. In Operaplus.cz, 28. 5. 2016. [online]. [cit. 13. 9. 2019]. Dostupné na internete: https://operaplus.cz/konwitschny-zenam-rozumi/?pa=1.

${ }^{31}$ KONWITSCHNY, P. - ROSENDAHL, I. Beschleunigtes Leben bringt keinen Frieden. [rozhovor]. In WELKER, Andrea (ed.). Peter Konwitschny. "Mensch, Mensch, Mensch!" Oper als Zentrum der Gegenwart, s. 476 .

${ }^{32}$ Napr. na premiére Verdiho Aidy v Oper Graz hádzala čast’ divákov na režiséra paradajky.

${ }^{33}$ Inscenácia Kálmánovej Čardášovej princeznej (Dresdner Semperoper, 1998) mala súdnu dohru. Po tom, čo vedenie divadla, reagujúc na protesty nespokojnej časti publika, pozmenilo niektoré časti inscenácie, sa režisér obrátil na súd so žiadostou o uznanie svojich autorských práv k inscenácii. Súd jeho nárok uznal.

${ }^{34}$ Tento typ škandálu sprevádzal aj prípravu bratislavskej inscenácie Halévyho Židovky. Z nej pre konflikt s režisérom odstúpila počas skúškového procesu hlavná predstavitelka, problematická bola tiež Konwitschného spolupráca so zborovým telesom SND.

${ }^{35}$ SMALLSHAW, S. Problems of Religion and Secularism Explored in Konwitschny's La Juive. In Seen and Heard International, 5. 4. 2019. [online]. [cit. 22. 9. 2019]. Dostupné na internete: https://seenandheardinternational.com/2019/04/problems-of-religion-and-secularism-explored-in-konwitschnys-la-juive/. 
productions that Peter Konwitschny has directed on European stages, including the Slovak National Theatre in Bratislava.

Príspevok je súčastou riešenia projektu APVV č. 15-0764 Slovenské divadlo a súčasná európska kultúra - kontinuita a diskontinuita.

\section{LITERATÚRA}

BAYER, Robert. Konwitschny ženám rozumie. In Operaplus.cz, 28. 5. 2016. [online]. [cit. 13. 9. 2019]. Dostupné na internete: https://operaplus.cz/konwitschny-zenam-rozumi/?pa=1. ISSN 1805-0433.

BLAHO, V. Bohéma antisentimentálna? In Monitoring divadiel na Slovensku, 8. 7. 2015. [online]. [cit. 20. 9. 2019]. Dostupné na internete: https://www.monitoringdivadiel.sk/recenzie/recenzia/bohema-antisentimentalna/. ISSN 2454-0129.

CARVALHO, Mário Vieira. Die Überlieferung dem Konformismus abgewinnen. In WELKER, Andrea (ed.). Peter Konwitschny. "Mensch, Mensch, Mensch!“ Oper als Zentrum der Gegenwart. Weitra : Verlag Bibliothek der Provinz, 2015, s. 152. ISBN 978-3-99028-436-0.

HOLENDER, Ioan. Don Carlos. Publikumsskandal - Kultproduktion. In WELKER, Andrea (ed.). Peter Konwitschny. "Mensch, Mensch, Mensch!“ Oper als Zentrum der Gegenwart. Weitra : Verlag Bibliothek der Provinz, 2015, s. 412. ISBN 978-3-99028-436-0.

JINDRA, Robert - KMEČOVÁ, Vladimíra. Halévyho Židovka ako predzvest' Gesamtkunstwerku. [rozhovor]. In Operaslovakia.sk, 6. 4. 2017. [online]. [cit. 21. 9. 2019]. Dostupné na internete: http://operaslovakia.sk/robert-jindra-halevyho-zidovka-ako-predzvest-gesamtkunstwerku/. ISSN 2453-6490.

KONWITSCHNY, Peter. Aida II. Frauen, Tod, Oper. In WELKER, Andrea (ed.). Peter Konwitschny. "Mensch, Mensch, Mensch!“ Oper als Zentrum der Gegenwart. Weitra : Verlag Bibliothek der Provinz, 2015, s. 248. ISBN 978-3-99028-436-0.

KONWITSCHNY, Peter - HOLTZ, Corinne. Bach inszenieren heisst mit der Endligkeit vertig werden. [rozhovor]. In Neue Zürcher Zeitung, 28. 5. 2011. [online]. [cit. 17. 9. 2019]. Dostupné na internete: https://www.nzz.ch/bach_inszenieren_heisst_mit_der_endlichkeit_fertig_ werden-1.10727684. ISSN 0376-6829.

KONWITSCHNY, Peter - KÄMPFER, Frank. Körper, Tod un Utopie. [rozhovor]. In WELKER, Andrea (ed.). Peter Konwitschny. "Mensch, Mensch, Mensch!“ Oper als Zentrum der Gegenwart. Weitra : Verlag Bibliothek der Provinz, 2015, s. 189 - 192. ISBN 978-3-99028-436-0.

KONWITSCHNY, Peter - ROSENDAHL, Ingolf. Beschleunigtes Leben bringt keinen Frieden. [rozhovor]. In WELKER, Andrea (ed.). Peter Konwitschny. "Mensch, Mensch, Mensch!“ Oper als Zentrum der Gegenwart. Weitra : Verlag Bibliothek der Provinz, 2015, s. 475 - 479. ISBN 978-3-99028-436-0.

KONWITSCHNY, Peter - SKRAMSTAD, Per-Erik - HOLTE, Kathrine. I do not consider myself a representative of the Regietheater. [rozhovor]. In Wagneropera.net. [online]. [cit. 20. 9. 2019]. Dostupné na internete: http://www.wagneropera.net/Interviews/Peter-Konwitschny-Interview-2009.htm.

KONWITSCHNY, Peter - VONGREJ, L’udovít. Príbeh Židovky nás učí, že musíme prestat’ s násilím a hladat viac lásky. [rozhovor]. In Operaslovakia.sk, 7. 4. 2017. [online]. [cit. 22. 9. 2019]. Dostupné na internete: https://operaslovakia.sk/peter-konwitschny-pribeh-zidovky-nas-uci-ze-musime-prestat-s-nasilim-a-hladat-viac-lasky/. ISSN 2453-6490.

RIENÄCKER, Gerd. 40-jähriges Bühnenjubiläum. In WELKER, Andrea (ed.). Peter Konwitschny. "Mensch, Mensch, Mensch!“ Oper als Zentrum der Gegenwart. Weitra : Verlag Bibliothek der Provinz, 2015, s. 166. ISBN 978-3-99028-436-0. 
SMALLSHAW, Sebastian. Problems of Religion and Secularism Explored in Konwitschny's La Juive. In Seen and Heard International, 5. 4. 2019. [online]. [cit. 22. 9. 2019]. Dostupné na internete: https://seenandheard-international.com/2019/04/problems-of-religion-and-secularism-explored-in-konwitschnys-la-juive/.

UNGER, Pavel. Janáčkov návrat s Konwitschného puncom. In Pravda, roč. 25, č. 261, s. 3, 11. 11. 2015. ISSN 1335-4050.

WELKER, Andrea (ed.). Peter Konwitschny. „Mensch, Mensch, Mensch!“ Oper als Zentrum der Gegenwart. Weitra : Verlag Bibliothek der Provinz, 2015. ISBN 978-3-99028-436-0. 525 s. ISBN 978-3-99028-436-0.

Michaela Mojžišová

Ústav divadelnej a filmovej vedy CVU SAV

Dúbravská cesta 9

84101 Bratislava

e-mail: michaela.mojzisova@savba.sk 